\title{
Biopesticidal Management of Pulse Beetle (Callosobruchus Chinensis L) in Chickpea Seeds
}

\author{
Md. Israfil Jahan ${ }^{1}$, Masum Ahmad ${ }^{2}$, Md. Sohanur Rahman ${ }^{3} \&$ Fakhar Uddin Talukder ${ }^{4}$ \\ 1 Department of Seed Science and Technology, Bangladesh Agricultural University, Mymensingh-2202, \\ Bangladesh \\ ${ }^{2}$ Professor, Department of Entomology, Bangladesh Agricultural University, Mymensingh-2202, Bangladesh \\ ${ }^{3}$ Scientific Officer, Department of Entomology, Bangladesh Jute Research Institute, Manik Mia Avenue, Dhaka- \\ 1207, Bangladesh \\ ${ }^{4}$ Scientific Officer, Pest Management Division, Bangladesh Jute Research Institute, Manik Mia Avenue, Dhaka- \\ 1207, Bangladesh \\ Correspondence: Md. Sohanur Rahman, Scientific Officer, Department of Entomology, Bangladesh Jute Research \\ Institute, Manik Mia Avenue, Dhaka-1207, Bangladesh. E-mail: sohanbau2010@gmail.com
}

Received: April 12, 2020 Accepted: May 7, 2020 Online Published: May 14, 2020

\begin{abstract}
The pesticidal efficacy of four locally available leaves of botanicals like neem (Azadirachta indica), datura (Datura stramonium), marigold (Tagetes erecta) and garlic (Allium sativum L.) tablet powders was assessed on pulse bettle (Callosobruchus chinensis L) through adult mortality and emergence, oviposition performance, seed damage, weight loss and germination of chickpea (Cicer arietinum). The above test biopesticides were tested at three different rates $(0.5 \mathrm{~g}, 1.0 \mathrm{~g}$ and $1.50 \mathrm{~g}$ powder $/ \mathrm{kg}$ of chickpea seeds). All the tested powder showed significant effect on the above parameters. The highest adult mortality was recorded when chickpea seeds were treated with datura leaf powder at $1.50 \mathrm{~g} / \mathrm{kg}$, whereas marigold showed the least effect on adult mortality. The powders used in the experiment effectively controlled oviposition and adult emergence of pulse beetle. The lowest number of adult emergence was obtained from chickpea seeds treated with datura leaf powder at $1.50 \mathrm{~g} / \mathrm{kg}$. The highest weight loss was observed in control seeds followed by marigold leaf powder $0.5 \mathrm{~g} / \mathrm{kg}$ gram seeds. Datura leaf powder treated seeds showed the lowest seed weight loss followed by neem, garlic and marigold. Plant powders had profound effect on seed germination. The highest germination was observed in treated seed with datura leaf powder at $1.50 \mathrm{~g} / \mathrm{kg}$ and the lowest germination in control seed followed by marigold leaf powder at $1.5 \mathrm{~g} / \mathrm{kg}$ treated seeds. The pesticidal effect on oviposition, adult mortality, adult emergence, and seed weight loss was directly proportional to leaf powder rates.
\end{abstract}

Keywords: leaf powder, biopesticide, insect damage, pulse crop, oviposition, adult emergence, seed germination

\section{Introduction}

Chickpea (Cicer arietinum L.) belongs to the Leguminosae family. It is the world's third most important food legume, and one of the most important pulse crops in Bangladesh. It is the third major pulse crop after grass pea and lentil (Islam et al., 1981 and Anon, 1998). The yield potential of present-day chickpea cultivar exceeds 4t/ha (Chaithra, 2009). However, average yield in Bangladesh is less than 0.8t/ha (BBS, 2011).

The pulse beetle, Callosobruchus chinensis Linn. (Coleoptera: Bruchidae), is a major pest of economically important leguminous grains, such as cowpeas, lentils, green gram, and black gram (Talukder and Howse, 1994; Raja et al. 2000; Mulatu and Gebremedhin, 2000; Park et al., 2003). Pulse seeds suffer a great damage during storage due to insect attack (Sharma, 1984).

Three species of pulse beetles, viz, Callosobruchus chinensis Linn.,C. analis Fab., and C. maculates Fab. have been reported from Bangladesh as the pest of stored pulses (Begum et al., 1984 and Alam, 1971). Among them C. chinensis cause enormous losses to almost all kind of pulses in storage condition. In Bangladesh, C. chinensis commonly called pulse beetle, but in America and Japan it is known as the cowpea weevil or adzuki bean beetle. The degree of damage varies with different kinds of legumes on the basis of exposure time, storage facilities and other factors associated with seeds. Under farmers' storage conditions, as high as 53 to $98 \%$ of grains in pulse crops like blackgram, grasspea, lentil and chickpea, were reported to be damaged by pulse beetle (C. chinensis) in 
Bangladesh (Anon, 1984). The rate of increases or decreases with the duration of storage under normal condition i.e., the longer the duration the higher the damage (Gujar and Yadav, 1978).

The extent of damage to pulse seeds is very high both qualitatively and quantitatively. There was a $55-69 \%$ loss in seed weight and $45-66 \%$ loss in protein content due to pulse beetle on chickpea. About $100 \%$ loss of pulse seeds was found due to pulse beetle infestation (Gujar and Yadav, 1978).

In the world, as many as 2400 plant species were known for their potential pesticidal properties and biological activity against a wide range of pests (Grainge and Ahmed, 1988).

A study conducted by Chavan et al. (1997) on the ovipositional preference of Callosobruchus chinensis for different cowpea lines and showed that rough seed surface were less attractive, resulting in a lower rate of grains infected.

Sharmila and Roy (1994) studied the effects of oviposition and development of the bruchid C. maculats on nine legume seeds under common storage conditions in the Bundelhand region of Madhya Pradesh, India. Bengal gram was most preferred both under choice and no choice conditions. However, under no choice condition, bruchids developed on green gram (Vigna radiata), cowpeas, lentils and red gram (pigeon pea).

It was reported that when mixed with stored-grains, leaf, bark, seed powder or oil extracts reduced oviposition as well as seed damage rates, and suppressed adult emergence of bruchids (Keita et al., 2001; Shaaya et al., 1997; Onu and Aliyu, 1995 and Talukder and Howse, 1994). Leaf powder of plant species like biskatali, marigold, castor, nishinda, dholkolmi, mahogany, dhutra, oleander and mango were also effective in reducing adult emergence in lentil and chickpea (Bhuiyan, 2001).

Shiau et al., (1994) studied the oviposition choice of $C$. maculatus, a stored products pest, by providing its females with different ratios of azuki beans $(V$. angularis) and chickpeas $(V$. radiata). The fraction of eggs laid on azuki beans increased with increasing ratio of azuki beans, whereas it decreased with a shorter duration of oviposition.

Ahmed (1992) observed that in all the seasons, lentil and chickpea were highly preferred for oviposition and the emergence of adults were considerably high, while gram and black gram were least preferred for oviposition except for high rates of adult emergence regarding gram and pigeon pea in summer.

The control of storage pests by using synthetic chemicals has become a common practice among farmers and stockholders. It is now widely known that chemical method has several concerns, which include health hazards to the users and grain consumers. It causes residual toxicity, environmental pollution and development of pesticide resistance against bruchids. Sometimes persistent pesticides accumulate in the higher food chain of both wildlife and human and become concentrated by bio magnification (Metcalf, 1975). The traditional method of controlling storage pests by sun-drying is safer to human health and environment. But this method is laborious, time consuming, often expensive and requires suitable drying yard, when large volume of stored grain is involved. Moreover, it depends on favorable weather conditions. Recently, the use of different plants and their derivatives has appeared as an effective alternative to synthetized insecticides in the control of various insect pests of food grains. Under storage conditions, this pest is controlled by synthetic insecticides which are prone to several limitations with respect to environmental hazards. In contrast, biopesticides are cheaper, more readily biodegradable, some of them being less toxic to mammals, more selective in action, and less subjected to pest resistance. Their main advantage is that they may be easily and cheaply produced by farmers and small-scale industries as crude, or partially purified extracts. The present study was undertaken to determine the efficacy of four different biopesticides made of leaf powder of local plants in the control of pulse beetle.

\section{Materials and Methods}

The study was carried out, from August to October 2018, in the laboratory of the Department of Entomology, Bangladesh Agricultural University (BAU), Mymensingh. Temperature in the laboratory ranged from 25 to $31^{\circ} \mathrm{C}$ and the air moisture content from 68 to $75 \%$. The laboratory was kept well aerated throughout the study.

\subsection{Pulse Beetle}

\subsubsection{Pulse Beetle as a Major Pest}

Among the insect pests attacking stored food grains, the pulse beetle known as an economically important one (Alam, 1971). Its larvae bore into pulse grains, which become unsuitable for human consumption and non-viable for replanting. A number of major pests of food grains under storage conditions were reported in Asia and Africa (Ogunwolu and Idowu, 1994; Okonkwo and Okoye, 1996; Raja et al., 2000; Mulatu and Gebremedhin, 2000; Tapondjou et al., 2002). 


\title{
2.1.2 Systematic Position
}

\author{
Phylum - Arthropoda \\ Class - Insecta \\ Sub class Pterygota \\ Division Endopterygota \\ Order - Coleoptera \\ Family - Bruchidae \\ Genus - Callosobruchus \\ Species - Callosobruchus chinensis $\mathrm{L}$
}

\subsubsection{Egg and Oviposition}

The female beetle oviposited within 24 hours, with 1 to 3 eggs were laid per pulse grain although many of them could be observed in a single grain (Raina, 1970). She also observed that the female laid on chickpea an average of 78 eggs ranging from 63 to 90 over a period of 8 days at $30^{\circ} \mathrm{C}$ and $70 \%$ of relative humidity. Lambrides (2000) reported that the texture, layer present on the seed coat of some chickpea varieties and small grains size might act as oviposition deterrents. The freshly laid eggs were translucent, smooth and shining but become pale yellowish or grayish white with age. Eggs were elongated and oval in shape (Alam, 1971).

\subsubsection{Larval Period}

Razzak and Pundy (1965) observed that the full grown larvae were curved and the dorsal body was raised into a segmented done like structure. According to Alam (1971) the full grown larva was $6 \mathrm{~mm}$ long, flesh strongly wrinkled, perfectly white except brown color at mouth region. Soon after hatching, seeds were bored by young larvae causing their weight losses with negative impact on seed quality for human consumption and germination.

\subsubsection{Pupal Period}

Dennis (1990) reported that the pupation took place inside the seed in a chamber covered by a thin window of testa prepared by a mature larva. The pupae were exerate type with a mean pupal duration of 2.5 days in summer and 4.25 days in winter (Bhuiyan and Peyara, 1978).

\subsubsection{Adult Emergence}

Before emergence, the adult remain a few days inside the pupal chamber. The adult emergence occurred by cutting a window hole and then pushing head and forelegs through it (Razzak and Pundey, 1965). The beetle was dark and incospicuous in color, its body being hair-clothed. Bhuiyan and Peyara (1978) reported that the head of the beetle is small, hypognathous and provided with short snout. The males were short lived and smaller than females. The adult was $4 \mathrm{~mm}$ long and distinguished from other species by the elevated ivory like spots near middle of the body (Alam, 1971). Arora and singh (1970) found that the adult generally more around the grains and were also capable of making short flights with hind wings. According to Bhuiyan and Peyara (1978), the longevity of male and female beetle is respectively 4.3 and 5.4 days in summer, or 7.4 and 9.2 days in winter. The life cycle of $C$. chinensis was completed in 30-32, 20-23, and 40-46 days in early summer, mid summer and winter, respectively.

\subsubsection{Nature and Extent Of Damage}

Begum et al., (1982) stated that in Bangladesh C. chipnensis L. was one of the major pests belonging to Callosobruchus spp. Which causes considerable damage to stored legume grains. The larval stage causes severe damage on pulse grains jeopardizing their quality for human consumption and germination. In a laboratory study, it was found that the initial presence of 4 larvae or one pair of Callosobruchus spp adult could completely damage $10 \mathrm{~g}$ of the pulse grain within 2-4 month depending on the type of the pulse, stage of maturity and species of the beetle. Gujar and Yadav (1978), recorded 55-60\% loss by seed weight and $45-66 \%$ loss in protein content due to pulse beetle. Chowdhury (1961) reported that the extent of weight losses on chickpea seeds under storage, due to C. chinensis and C. maculatus could reach up to $100 \%$ over a period of one year.

\subsection{Chickpea}

Among food legumes, chickpea is known as the most nutritive pulse extensively used as protein adjunct to starchy diet (Sastri, 1950; Duke, 1981; Huisman and Van der Poel, 1994). Chickpea after dehulling is valued for its nutritive seeds with high protein content (12.3-31.5\%). Chickpea seeds are eaten fresh as green vegetables, parched, fried, roasted and boiled as snack food, sweet and condiments. They contain as much as $38-59 \%$ carbohydrate, $3 \%$ fiber, $4.8-5.5 \%$ oil, $3 \%$ ash, $0.2 \%$ calcium, and $0.3 \%$ phosphorus. The digestibility of protein and carbohydrate 
varies, respectively, from 76-78\% and from 57-60\% (Huisman and Van der poel, 1994). They also contain essential amino acids like isoleucine, leucine, lysine, phenylalanine, and valine (Karim and Fattah, 2006). It is a good and cheap source of protein for people in developing countries (especially in South Asia), who are largely vegetarian either by choice or economic reasons. Moreover, they are rich in minerals (phosphorus, calcium, magnesium, iron and zinc), fiber, unsaturated fatty acids and $\beta$-carotene (Jukanti et al., 2012). Chickpea meets $80 \%$ of its nitrogen requirement from symbiotic nitrogen fixation and can fix up to $140 \mathrm{~kg} \mathrm{~N} /$ ha from air (Ullah et al., 2002).

\subsection{Mass Culture of The Pulse Beetle}

Pulse beetles were reared by maintaining insects on chickpea seeds under room conditions $\left(27^{0} \mathrm{C}, 70 \%\right.$ air moisture) in the Laboratory. Fifty (50) pairs of adult male and female pulse beetles were placed in a glass jar containing chickpea seeds. The jar was then covered with black cotton cloth and the beetles were allowed for free mating and oviposition over 7 days in the aforementioned environmental conditions in a dark place. The parent beetles were removed and pulses containing eggs were kept in a jar for further development and getting new adults. Rearing of the insects was continued for the whole experimental period.

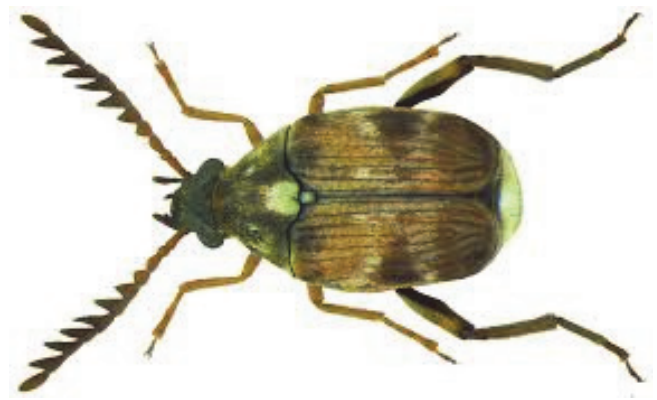

Plate 1. Adult pulse beetle

\subsection{Botanical Species Tested as Biopesticides}

Three different rates of four biopesticides $(0.5,1.0$ and $1.5 \mathrm{gm} / \mathrm{kg}$ seeds) were used for the experiment, namely, Neem (Azadirachta indica - Meliaceae), Datura (Datura stramonium - Solanaceae), Garlic (Allium sativum L.Liliaceae), Marigold (Tagetes erecta - Calenduleae).

\subsection{Preparation of Plant Material}

All four treatments made of leaf power of local plant species were assessed for their insecticidal potency against pulse beetle. They were collected from the local market of Mymensingh, Bangladesh. The test materials have been oven dried at $60^{\circ} \mathrm{C}$ for three to four days until they were reached a constant weight before powder preparation. Spice powders were prepared by pulverizing the oven dried seeds/cloves with the help of a steel blender. Then the dust was passed through a 25 unit diameter sieve to obtain fine and uniform powder.

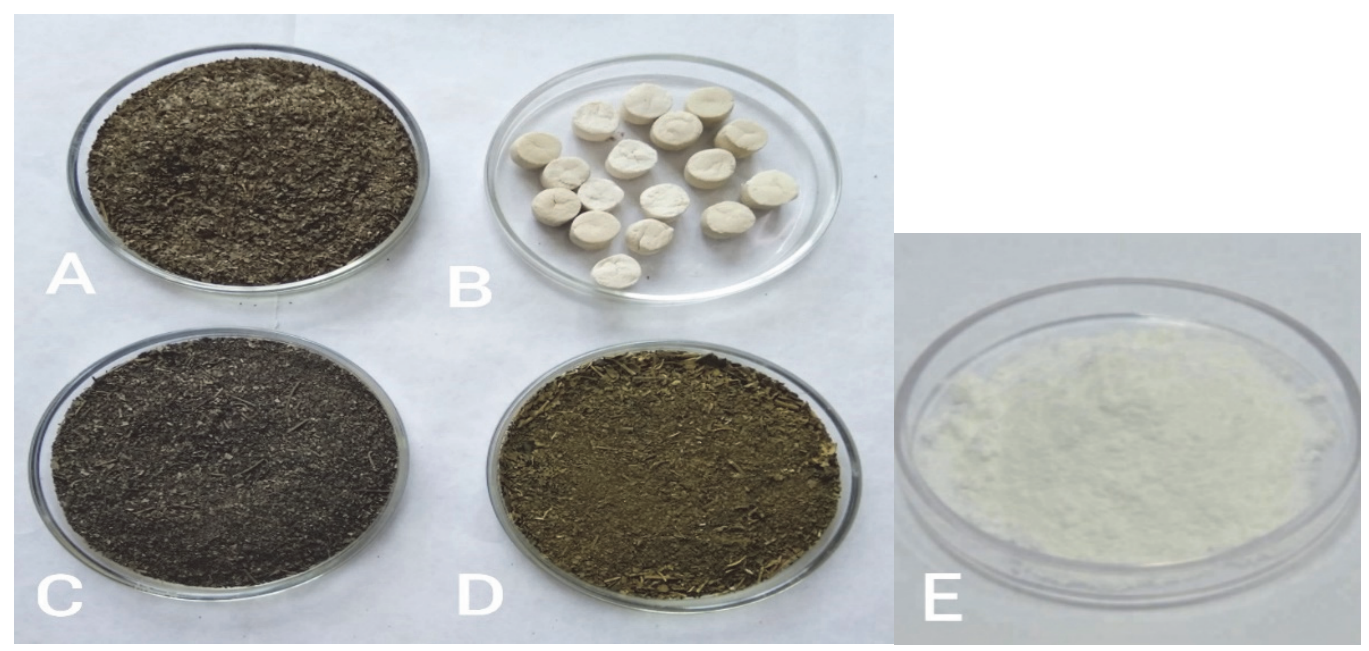

Plate 2. Prepared Botanical Materials: (A) Neem leaf powder, (B) Garlic tablet, (C) Marigold leaf powder, (D) Datura leaf powder, (E) Garlic tablet in broken form 


\subsection{Collection of Chickpea Seeds}

Chickpea (C. arietinum) seeds were used in this experiment as host of pulse beetle and collected on local market of Mymensingh. The seeds were completely free from insects, microorganisms, food grains and other materials. There were no other crop seeds and foreign materials in the seed lot. Before being stored, seeds were properly dried and kept free of any insecticide treatment.

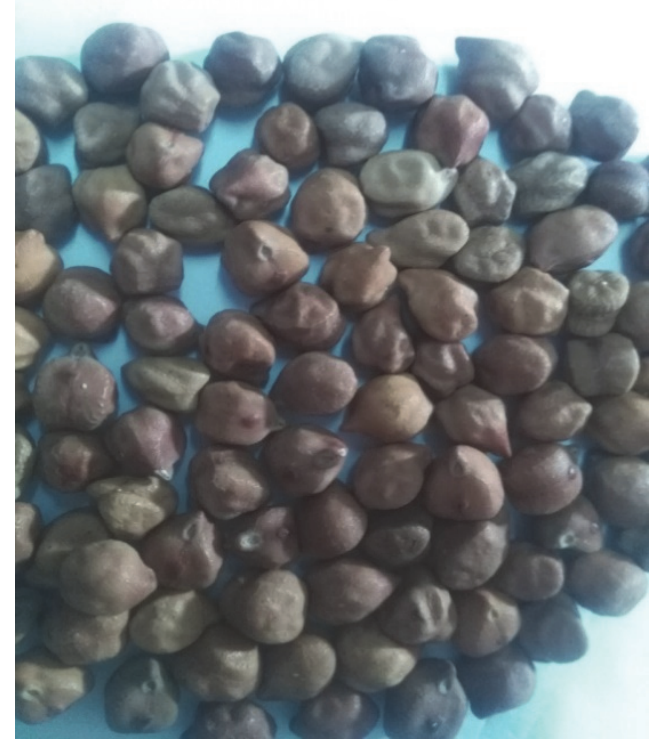

Plate 3. Fresh chickpea seed

\subsection{Insect Bioassay}

The powders were mixed up with gram seeds following three different rates $(1.5,1.0$, and $0.50 \mathrm{~g} / \mathrm{kg}$ seeds) in separate petridishes of $90 \mathrm{~mm}$ in diameter. Five pairs of newly emerged adult beetles were released into each Petridish containing treated seeds. Three replications were made for each treatment, the control included. Petridishes were kept at the room temperature without any disturbance. The efficacy of powders against pulse beetle was evaluated with due consideration of parental mortality, number of eggs, adult emergence, seed weight loss and germination regarding treated and untreated seeds.

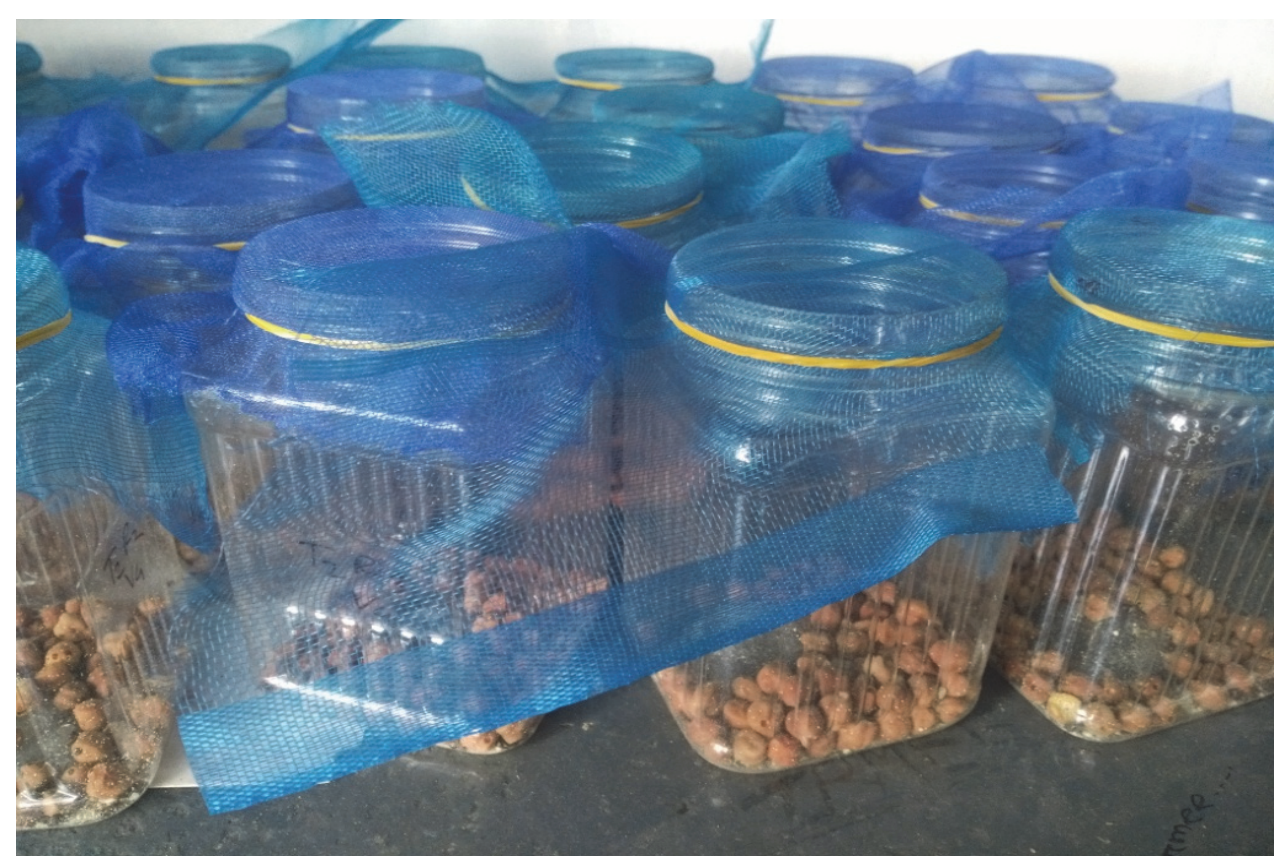

Plate 4. Experimental set up of chickpea seeds with treatments 


\subsection{Mortality and Oviposition Test of Pulse Beetle}

Data on the parental mortality was recorded daily from 1st to 7 th day of pulse beetle release. After seven days, beetle mortality rate was calculated as follows:

$$
\% \text { mortality }=\frac{\text { Number of dead insects }}{\text { Total Number of insects released }} \times 100
$$

After seven days, seeds were carefully checked using a magnifying glass so that seeds with eggs or without eggs were separated and their total number determined afterwards. After separation total number of egg bearing seeds and total number of eggs were recorded.

\subsection{Effect of Plant Powders on Adult Emergence}

After hatching beetle larvae penetrated to attack cotyledon before getting out as adult by making holes on seed coat. The number of emerged adult beetles was counted daily from the first to the last day emergence. Pulse beetle started emerging after 24 days of release. The emerged beetles were counted and removed every day before removing them from the petridish upto 7 consecutive days.

\subsection{Seed Weight Loss Assessment of Chickpea Seeds}

The seeds were separated from dust and dead bodies of pulse beetle by winnowing. Clean seeds in each petridish were separately weighted. The weight loss of pulse seed was calculated by subtracting final weight from initial weight as follows:

$$
\text { Weight loss }(\%)=\frac{\mathrm{A}-\mathrm{B}}{\mathrm{A}} \times 100
$$

Where, $\mathrm{A}=$ Initial weight, $\mathrm{B}=$ Final weight

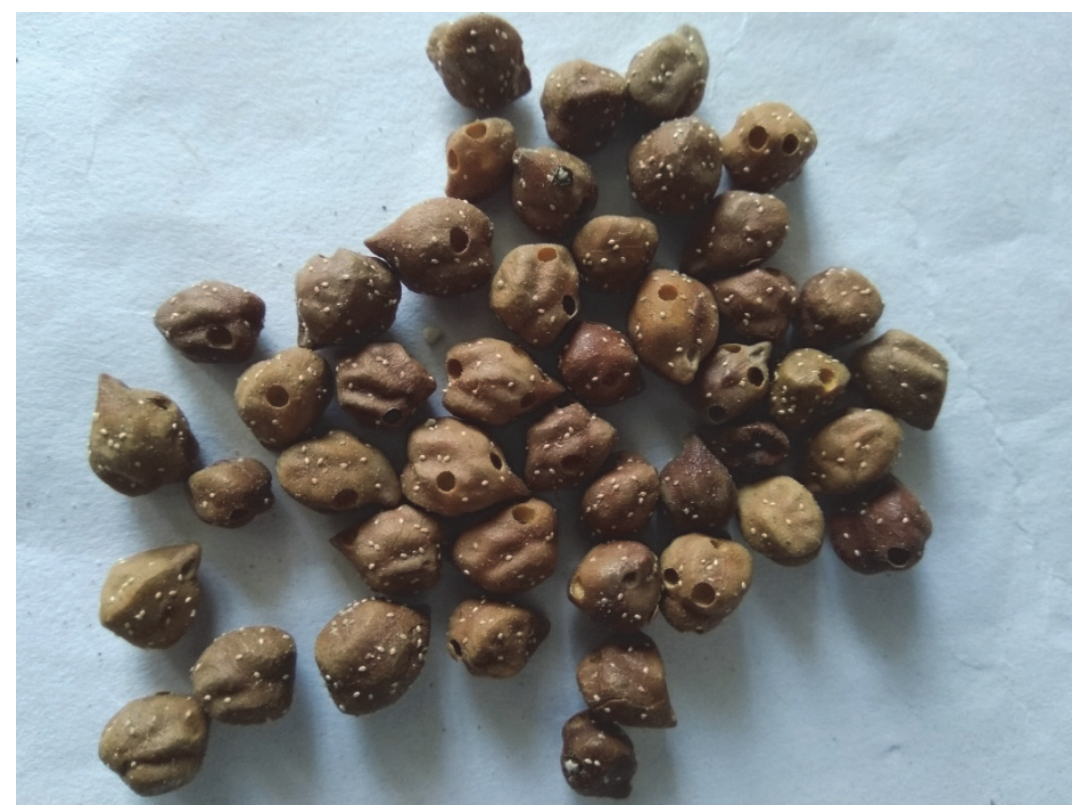

Plate 5. Damaged 1gram seed after 1 month

\subsection{Seed Germination Test}

The effect of treatments on seed germination and viability was determined after 28 days of storage. Seed germination was tested following standard procedures. About 75 seed sub-samples were germinated under laboratory conditions on moistened blotter paper covering petridishes being arranged in three replicates. The number of seedlings from each petridish was recorded after 5 days for determining their germination rate as follows:

$$
\text { Germination }(\%)=\frac{\mathrm{NG}}{\mathrm{TG}} \times 100
$$

Where,

$\mathrm{NG}=$ Number of seeds that germinated 
$\mathrm{TG}=$ Total number of test seeds

\subsection{Statistical Analysis}

Data obtained were statistically analyzed in accordance with two factors Completely Randomized Design (CRD) and treatment means were compared by Duncan's Multiple Range Test (DMRT).

\section{Results and Discussion}

The pesticidal effect of datura leaf powder, neem leaf powder, marigold leaf powder and garlic tablet powder on pulse beetle, Callosobruchus chinensis $\mathrm{L}$ at different ratio were investigated. The result of the experiment have been presented and discussed under following sub heading.

\subsection{Effect of Different Powders on The Adult Mortality of Pulse Beetle}

Table 1. Effect of plant powders at various ratios on adult mortality of pulse beetle, Callosobruchus chinensis L

\begin{tabular}{ccc}
\hline Treatments & Doses $(\mathrm{g} / \mathrm{kg})$ & Adult mortality $(\%)$ \\
\hline \multirow{2}{*}{ Datura leaf powder } & 0.50 & $61.0 \mathrm{c}$ \\
& 1.00 & $77.0 \mathrm{a}$ \\
& 1.50 & $81.0 \mathrm{a}$ \\
\hline \multirow{2}{*}{ Neem leaf powder } & 0.50 & $50.0 \mathrm{~d}$ \\
& 1.00 & $61.0 \mathrm{c}$ \\
& 1.50 & $78.0 \mathrm{a}$ \\
\hline \multirow{2}{*}{ Garlic tablet powder } & 0.50 & $49.0 \mathrm{~d}$ \\
& 1.00 & $61.0 \mathrm{c}$ \\
Marigold leaf powder & 1.50 & $70.0 \mathrm{~b}$ \\
& 0.50 & $32.0 \mathrm{f}$ \\
Control & 1.00 & $42.0 \mathrm{e}$ \\
LSD & 1.50 & $61.0 \mathrm{c}$ \\
CV (\%) & & $22.0 \mathrm{~g}$ \\
& & 5.12 \\
\end{tabular}

The mean numbers of adult mortality on gram seeds treated with different powders at different rate at laboratory condition are presented in table 1. It was revealed that lowest number of adult mortality from untreated seeds 22 compared to all other treatments. The number of adult mortality was higher at higher ratio of all powders. Among the treated seeds, the highest number of adult mortality 81 was found from seeds of datura leaf powder @ $1.5 \mathrm{~g} / \mathrm{kg}$ followed by neem leaf powder @ $1.5 \mathrm{~g} / \mathrm{kg} 78$. The lowest number of mortality 32 from seeds treated with marigold leaf powder@ $0.5 \mathrm{~g} / \mathrm{kg}$ followed by marigold leaf powder @ $1.0 \mathrm{~g} / \mathrm{kg} 42$. This result was similar to the findings reported by Tapondjou (2002) indicating that the adult mortality was more when stored seeds were treated with some indigenous plant powder and oils. 


\subsection{Effect of Different Powders on The Oviposition Inhibition of Pulse Beetle}

Table 2. Effect of plant powders at various ratios on egg of pulse beetle, Callosobruchus chinensis L

\begin{tabular}{lll}
\hline Treatments & Doses $(\mathrm{g} / \mathrm{kg})$ & No. of laid eggs / 20 gm seed \\
\hline & 0.50 & $54.0 \mathrm{hi}$ \\
Datura leaf powder & 1.00 & $51.0 \mathrm{i}$ \\
& 1.50 & $40.0 \mathrm{j}$ \\
\hline & 0.50 & $65.0 \mathrm{ef}$ \\
Neem leaf powder & 1.00 & $63.0 \mathrm{fg}$ \\
& 1.50 & $58.0 \mathrm{gh}$ \\
\hline & 0.50 & $72.0 \mathrm{~cd}$ \\
Garlic tablet powder & 1.00 & $70.0 \mathrm{de}$ \\
& 1.50 & $68.0 \mathrm{def}$ \\
\hline & 0.50 & $80.0 \mathrm{~b}$ \\
Marigold leaf powder & 1.00 & $78.0 \mathrm{bc}$ \\
& 1.50 & $75.0 \mathrm{bcd}$ \\
\hline Control & & $87.0 \mathrm{a}$ \\
LSD & & 6.73 \\
CV $(\%)$ & 4.46 \\
\hline
\end{tabular}

It was found that the powders had profound influence on the egg deposition by the beetles. Number of egg laid varied significantly when seeds were treated with different powders at different ratios (Table 2). Mean number of eggs increased gradually with the decrease of ratios of powder. Higher number of eggs $87 / 20 \mathrm{gm}$ seed was laid on the untreated seeds. Among the seeds treated with powders, the highest number of eggs 80/20 gm seed was laid on on seeds treated with marigold leaf powder @ $0.5 \mathrm{~g} / \mathrm{kg}$. The lowest number eggs 40/20 gm seed was deposited in seeds treated with datura leaf powder @ 1.5g/kg which was followed by neem leaf powders @ $1.5 \mathrm{~g} / \mathrm{kg} 58 / 20$ gm seed /, garlic tablet powder @ $1.5 \mathrm{~g} / \mathrm{kg} 68$, marigold leaf powder @ $1.5 \mathrm{~g} / \mathrm{kg} 75$. The oviposition inhibition was more at higher ratios than at lower ratios of all the plant powders.

Among the seed treated with powders, the highest number of egg bearing seeds (80) from seed treated with marigold leaf powder $@ 0.5 \mathrm{~g} / \mathrm{kg}$. The lowest number of egg bearing seeds 40 from seeds treated with darura leaf powder@1.5 g/kg. This result was similar to the findings reported by Rouf et at.(1996) indicating that the oviposition was inhibited when stored seeds were treated with some botanicals such as neem, nishinda and biskatali leaf powder.

\subsection{Effect of Different Powders on The Adult Emergence of Pulse Beetle}

Table 3. Effect of plant powders at various ratios on adult emergence of pulse beetle, Callosobruchus chinensis L

\begin{tabular}{ccc}
\hline Treatments & Doses $(\mathrm{g} / \mathrm{kg})$ & Adult emergence $(\%)$ \\
\hline \multirow{2}{*}{ Datura leaf powder } & 0.50 & $26.00 \mathrm{ef}$ \\
& 1.00 & $19.67 \mathrm{~g}$ \\
& 1.50 & $11.11 \mathrm{~h}$ \\
\hline \multirow{2}{*}{ Neem leaf powder } & 0.50 & $33.67 \mathrm{c}$ \\
& 1.00 & $27.33 \mathrm{de}$ \\
Garlic tablet powder & 1.50 & $21.00 \mathrm{fg}$ \\
\hline Marigold leaf powder & 0.50 & $41.00 \mathrm{~b}$ \\
& 1.00 & $32.33 \mathrm{~cd}$ \\
& 1.50 & $21.33 \mathrm{fg}$ \\
\hline
\end{tabular}




\begin{tabular}{ccc} 
& 1.00 & $42.00 \mathrm{~b}$ \\
& 1.50 & $31.00 \mathrm{cde}$ \\
\hline Control & & $51.33 \mathrm{a}$ \\
LSD & & 5.95 \\
CV $(\%)$ & & 8.48 \\
\hline
\end{tabular}

It was noted from the results of present investigation that the number of adult emergence was greatly reduced by the applicatioin of powders on the seeds. The number of adult emergence in the treated seeds ranged from $11.11 \%$ to $44.67 \%$ (Table 3). Among the treated seeds, the highest number of adult emergence (44.67\%) from seeds trated with marigold leaf powder @ $0.5 \mathrm{~g} / \mathrm{kg}$. The lowest number of adult emerged $(11.11 \%)$ from seeds treated with datura leaf powder@1.5 g/kg which was followed by neem leaf powder@1.5 g/kg (21\%), garlic tablet powder @ $1.5 \mathrm{~g} / \mathrm{kg}(21.33 \%)$, marigold leaf powder @ $1.5 \mathrm{~g} / \mathrm{kg}(31 \%)$. The results suggest good potentiality for use of datura and neem leaf powder as protectants in storage pest management in Bangladesh. This result was similar to the findings reported by Latif et al., (2012) indicating that the adult emergence was inhibited when stored seeds were treated with some indigrnous plant powders.

\subsection{Effect of Different Powders on Seed Weight Loss Due to Infestation of Pulse Beetle}

The pulse beetle caused damage to gram seeds in the petridish. The larvae fed on the internal contents of seeds for their growth and development. Pupae formation takes place inside the seeds and finally emerged as adult from the seed creating hole(s) on gram seeds. The effect of different ratios of powders on percent seed weight loss by the attack of pulse beetle was statistically significant at $1 \%$ level of probability at Table 4 .

Table 4. Effect of plant powders at various ratios on seed weight loss infested by pulse beetle

\begin{tabular}{lll}
\hline Treatments & Doses $(\mathrm{g} / \mathrm{kg})$ & Weight loss $(\%)$ \\
\hline \multirow{3}{*}{ Datura leaf powder } & 0.50 & $3.20 \mathrm{i}$ \\
& 1.00 & $2.40 \mathrm{k}$ \\
& 1.50 & $1.60 \mathrm{~m}$ \\
\hline \multirow{2}{*}{ Neem leaf powder } & 0.50 & $4.30 \mathrm{~g}$ \\
& 1.00 & $3.00 \mathrm{ij}$ \\
& 1.50 & 2.501 \\
\hline & 0.50 & $6.10 \mathrm{e}$ \\
Garlic tablet powder & 1.00 & $4.90 \mathrm{f}$ \\
& 1.50 & $3.80 \mathrm{~h}$ \\
\hline & 0.50 & $9.00 \mathrm{~b}$ \\
Marigold leaf powder & 1.00 & $7.88 \mathrm{c}$ \\
& 1.50 & $6.33 \mathrm{~d}$ \\
\hline Control & & $14.08 \mathrm{a}$ \\
LSD & & 0.05 \\
CV $(\%)$ & 4.08 \\
\hline
\end{tabular}

The percent of seed weight loss was inversely proportional to ratios .The Highest weight loss was recorded from untreated seeds $(14.08 \%)$. Among the plant powders, the lowest weight loss $(1.6 \%)$ was recorded from the seeds treated with datura leaf powder @ $1.5 \mathrm{~g} / \mathrm{kg}$ followed by datura leaf powder $@ 1 \mathrm{~g} / \mathrm{kg}(2.40 \%)$, neem leaf powder @ $1.5 \mathrm{~g} / \mathrm{kg}(2.5 \%)$ and garlic tablet @ $1.5 \mathrm{~g} / \mathrm{kg}(3.80)$. Among the seeds treated with plant powder, the highest weight loss (9.00\%) was recorded from the seeds treated with marigold @ $0.5 \mathrm{~g} / \mathrm{kg}$ (Table 4). This result with similar to the findings reported by Rouf et al., (1996) indicating that the seed weight loss was protected when stored seeds were treated with some botanicals such as neem, nishinda and biskatali leaf powder. 


\subsection{Effect of Different Powders on Seed Germination Due to Infestation of Pulse Beetle}

Table 5. Effect of plant powders on seed germination of chickpea infested by pulse beetle

\begin{tabular}{ccc}
\hline Treatments & Doses $(\mathrm{g} / \mathrm{kg})$ & Germination $(\%)$ \\
\hline \multirow{2}{*}{ Datura leaf powder } & 0.50 & $82.67 \mathrm{ab}$ \\
& 1.00 & $83.00 \mathrm{ab}$ \\
\multirow{3}{*}{ Neem leaf powder } & 1.50 & $85.00 \mathrm{a}$ \\
& 0.50 & $77.67 \mathrm{bcd}$ \\
& 1.00 & $80.00 \mathrm{abcd}$ \\
Garlic tablet powder & 1.50 & $82.00 \mathrm{ab}$ \\
\hline \multirow{2}{*}{ Marigold leaf powder } & 0.50 & $81.00 \mathrm{abc}$ \\
& 1.00 & $80.00 \mathrm{abcd}$ \\
Control & 1.50 & $78.00 \mathrm{bcd}$ \\
LSD & 0.50 & $75.00 \mathrm{cde}$ \\
CV $(\%)$ & 1.00 & $73.00 \mathrm{de}$ \\
& 1.50 & $70.00 \mathrm{f}$ \\
\hline
\end{tabular}

The pulse beetle caused damage to gram seed in petridish. Plant powders have profound effect on germination of seed. It is shown in the table 5 . Among the seed the lower germination in untreated seed (65\%). In the treated seed the lowest germination was observed from the seeds treated marigold @ $1.5 \mathrm{~g} / \mathrm{kg}(70 \%)$. The Highest germination was observed in the treated seeds of datura leaf powder @ $1.5 \mathrm{~g} / \mathrm{kg} 85$ followed by datura leaf powder @ $1 \mathrm{~g} / \mathrm{kg}$ 83 and neem leaf powder@1.5 g/kg 82. This result was similar to the findings reported by Tabu et al. (2012).

\section{Conclusion}

Among the four powders, datura leaf powder was found most effective against the oviposition of pulse beetle. The results suggest good potentiality for use of datura and neem leaf powder as protectants in storage pest management in Bangladesh. The percent of seed weight loss due to pulse beetle infestation increased with the decreased of ratios of all plant powders.

\section{Conflict of interest}

The authors have no conflict of interest to disclose.

\section{Authors' contribution}

Md. Israfil Jahan contributed in conducting the experiment and analysing data. Masum ahmad provided help for the experimental design. Md. Sohanur Rahman contributed in data presentation, analysing data, searching journal for publication and finally manuscript processing \& writing of this article. Fakhar Uddin Talukder helped in data prosessing. This article was read and approved by all authors for final Publication.

\section{References}

Ahmed, K. S. (1992). Studies on the population growth of pulse beetle in different stored pulses and their control. MS Thesis. BAU, Mymensingh. P.50.

Alam, M. Z. (1971). Pest of stored grains and other stored products and their control. The Agriculture Information Service, Dhaka. p.61.

Ali, M. R., \& Rahman, M. M. (2006). Screening of different pulses as host for resistance against C. maculatus Fab Journal of Subtropical Agriculture Research Dev., 4(1), 83-89.

Ali, M. R., Rahman, M. M., Ali M., \& Quamruzzaman, A. K. M. (1999). Studies on the host preference of pulse beetle, C. chinensis Linn. to different pulses. Journal of Agricultural Education and Technology, 2(2), 139144.

Anonymous. (1984). Pulse beetle incidence in stored pulses and control measures. Annual Report. Legume Post harvest Technology, BARI, Gazipur, Bangladesh, pp.6-13.

Anonymous. (1998). Statistical Yearbook of Bangladesh. Bangladesh Bureau of Statistics, Ministry of Planning, 
Govt. People's Republic of Bangladesh. pp. 61-64.

Arora, G. L., \& Singh, T. (1970). The biology of C. chinensis (2) (Coleoptera: Bruchidae). Bull. Punjab Univ., 21(1-11), 55-111.

BBS. (2011). Yearbook of Agricultural Statistics of Bangladesh, 23rd Edition Bangladesh Bureau of Statistic, Ministry of Planning, Govt. of the People's Republic of Bangladesh, Dhaka. pp. 96.

Begum, A., Rahman, M. S., \& Seal, D. R. (1982). Comparative morphology of larval instars of C. chinensis L. and C. analis F., Bangladesh Journal of Zoology, 10(1), 16-79.

Begum, A., Debnath, S. K., \& Seal, D. R. (1984). Studies on the food, temperature and humidity on the fecundity and development of C. analis Fab. Bangladesh Journal of Zoology, 12(2), 71-78.

Bhuiyan, M. S. I., \& Peyara, S. A. (1978). Studies on the biology of pulse beetle C. chinensis L. on stored pulse in Bangladesh. Journal of Agricultural Science, 5(1), 93-97.

Chaithra, M. (2009). Studies on Seed-borne Fungal Parhogens of Chickpea and their Management with special reference to Fusarium solani (Mart.) Sacc. University of Agricultural Sciences, Dharwad (Institute).

Chavan, P. H., Yesbir, S., Singh, S. P., \& Singh, Y. (1997). Ovipositional preference of C. chinensis for cowpea lines. Indian Journal of Entomology, 59(3), 295-303.

Chowdury, A. R. (1961). Pulse beetle, agriculture Research achievement in East Pakistan (1960-1961). Directorate of Agriculture, East Pakistan, Dacca. pp. 106-107.

Dennis, S., \& Hill, L. (1990). Pests of stored products and their control. Belhaven Press, London. p. 274.

Duke, J. A. (1981). Handbook of legumes of world economic importance. Plenum Press, New York, United States. pp. 52-57.

Grainge, M., \& Ahmed, S. (1988). Handbook of plants with pest control properties. John Wiley and Sons. New York, p. 470.

Gujar, G. T., \& Yadav, T. D. (1978). Feeding of C. maculatus Fab. Reared on different food and temperatures. Journal of Stored Product Research, 22(2), 71-75.

Huisman, J., \& Van der Poel, A. F. B. (1994). Aspects of the nutritional quality and use of cool season food legumes in animal feed. Wageningen, The Netherlands, pp. 5376. https://doi.org/10.1007/978-94-011-0798-3_2

Islam, M. Q., Sarker, A. T., Quader, M., \& Begum, L. (1981). Status of Chickpea Improvement at BARI. In AK Kaul (Ed.), Proc. National Workshop on Pluses at Joydebpur (pp. 56-64).

Jukanti, A. K., Gaur, P. M., Gowda, C. L. L., \& Chibbar, R. N. (2012). Nutritional quality and health benefits of chickpea (Cicer arietinum L.). Brazil Journal of Nutrition, 108, 512-526. https://doi.org/10.1017/s0007114512000797

Karim, M. F., \& Fattah, Q. A. (2006). Changes in biocomponents of chickpea (Cicer arietinum L.) sprayed with potassium napthenate and napthenic acetic acid. Bangladesh Journal of Botany, 35(1), 39-43.

Keita, S. M., Vincent, C., Schmit, J. P., Arnason, J. T., \& Belanger, A. (2001). Efficacy of essential oil of Ocimum basilicum L. and $O$. gratissimum L. applied as an insecticidal fumigant and powder to control Callosobruchus maculatus (Fab.) (Coleoptera: Bruchidae). Journal of Stored Product Research, 37(4), 339-349. https://doi.org/10.1016/s0022-474x(00)00034-5

Lambrides, C. J., \& Imrie, B. C. (2000). Susceptibility of mungbean varieties to the bruchid species $C$. chinensis L., C. maculatus F., C. phaseoli G. Australian Journal Agriculture Research, 51(1), 85-89. https://doi.org/10.1071/ar99051

Latif, M. A., Laizu, M., \& Akhter, N. (2012). Evaluation of dry leaf powder of some indigenous plants against pulse beetle, Callosobruchus chinensis L. infesting mungbean seeds. Bangladesh Journal of Entomology, $22(2), 21-31$.

Metcalf, R. L. (1975). Insecticides in pest management. In: Metcalf RL and Luckman, W. (eds.) Introduction to insect pest management. Willey International Science, New York. pp. 235-273.

Mulatu, B., \& Gebremedhi, T. (2000). Oviposition-deterrent and toxic effects of various botanicals on the Adzuki bean beetle, Callosobruchus chinensis L. Insect Science and its Application. Journal of Pest Management, 20(1), 33-38. https://doi.org/10.1017/s174275840001780x

Ogunwolu, O., \& Idowu, O. (1994). Potential of powdered Zanthoxylum zanthoxyloides (Rutaceae) root bark and 
Azadirachta indica (Meliaceae) seed for control of the cowpea seed bruchid, Callosobruchus maculatus (Bruchidae) in Nigeria. Journal of African Zoolog, 108(8), 521-528. https://doi.org/10.1016/02612194(95)00088-7

Okonkwo, E. U., \& Okoye, W. I. (1996). The efficacy of four seed powders and the essential oils as protectants of cowpea and maize grains against infestation by Callosobruchus maculatus (Fabricius) (Coleoptera: Bruchidae) and Sitophilus zeamais (Motschulsky) (Coleoptera: Curculionidae) in Nigeria. International Journal of Pest Management, 42(3), 143-146. https://doi.org/10.1080/09670879609371985

Onu, I., \& Aliyu, M. (1995). Evaluation of powdered fruits of four peppers (Capsicum spp.) for the control of Callosobruchus maculatus (F) on stored cowpea seed. International Journal of Pest Management, 41(3), 143-145. https://doi.org/10.1080/09670879509371939

Raja, N., Albert, S., Babu, A, Ignacimuthu, S., \& Dorn, S. (2000). Role of botanical protectants and larval parasitoid Dinarmus vagabundus (Timberlake) (Hymenoptera: Pteromalidae) against Callosobruchus maculatus Fab. (Coleoptera: Bruchidae) infesting cowpea seeds. Malaysian Applied Biology, 29(1-2), 55-60. https://doi.org/10.15406/mojbm.2017.02.00063

Razzak, R. L., \& Pundey, N. D. (1965). A life history study of the pulse beetle C. chinensis L. Journal of seed Technology, 3(2), 119-123.

Rouf, F. M., Sarder, M. A., \& Ahmed, K. S. (1996). Individual and combined effects of some plant materials for protection of lentil seeds against pulse beetle. C. chinensis L. Bangladesh Journal of Entomology, 6(1-2), 1321.

Sastri, B. N. (1950). The wealth of India, A dictionary of Indian raw materials and industrial Products. Vol. II. Council of Scientific \& Industrial Research, New Delhi pp. 427. https://doi.org/10.1126/science.114.2950.49a

Shaaya, E., Kostjukovski, M., Eilberg, J., \& Sukprakarn, C. (1997). Plant oils as fumigants and contact insecticides for the control of stored-product insects. Journal of Stored Product Research, 33(1), 7-15. https://doi.org/10.1016/s0022-474x(96)00032-x

Shiau, Y. S., Lai, L., \& Hong, S. B. (1994). Effects of ovipositional behavior on host preference of C. maculatus. Chinese Journal of Entomology, 14(2), 245-253.

Southgate, B. J. (1979). Biology of Bruchidae. Annual Review of Entomology, 24(1), 449-473.

Talukder, F. A., \& Howse, E. (1994). Repellent, toxic and food protectant effects of pithraj, Aphanamixis polystachya extracts against the pulse beetle. Callosobruchus chinensis in storage. Journal Chemical Ecology, 20(4), 221-232. https://doi.org/10.1007/bf02059586

Tapondjou, L. A., Adler, C., Boud, H., \& Fontem, D. A. (2002). Efficacy of powder and essential oil from Chenopodium ambrosioides leaves as post-harvest grain protectants against six-stored product beetles. Journal of Stored Product Res., 38(4), 395-402. https://doi.org/10.1016/s0022-474x(01)00044-3

Ullah, A., Bakht, J., Shafi, M., Shah, W. A., \& Islam, Z. U. (2002). Effect of various irrigation levels on different chickpea varieties. Asian Journal of Plant Science, 1(4), 355-357.

\section{Copyrights}

Copyright for this article is retained by the author(s), with first publication rights granted to the journal.

This is an open-access article distributed under the terms and conditions of the Creative Commons Attribution license (http://creativecommons.org/licenses/by/4.0/). 